\title{
Manganese induces apoptosis of human B cells: caspase- dependent cell death blocked by Bcl-2
}

Nicolas Schrantz ${ }^{1}$, Dominique A. Blanchard ${ }^{1}$, Françoise Mitenne ${ }^{2,3}$, Marie-Thérèse Auffredou ${ }^{1}$, Aimé Vazquez ${ }^{1}$ and Gérald Leca ${ }^{\star, 2,3}$

1 INSERM U131, 32 rue des carnets, 92140 Clamart, France

2 INSERM CJF 9502, 32 rue des carnets, 92140 Clamart, France

${ }^{3}$ Association Claude Bernard Research Center, 32 rue des carnets, 92140 Clamart, France

* corresponding author: Gérald Leca, PhD, INSERM CJF 9502, 32 rue des carnets, 92140 Clamart, France. tel: 331412880 60;

fax: 331412880 51; e-mail: gleca@infobiogen.fr

Received 1.7.98; revised 15.12.98; accepted 12.2.99

Edited by J.C. Ameisen

\section{Abstract}

Manganese ions block apoptosis of phagocytes induced by various agents. The prevention of apoptosis was attributed to the activation of manganous superoxide dismutase (Mn-SOD) and to the antioxidant function of free $\mathrm{Mn}^{2+}$ cations. However, the effect of $\mathrm{Mn}^{2+}$ on B cell apoptosis is not documented. In this study, we investigated the effects of $\mathrm{Mn}^{2+}$ on the apoptotic process in human $\mathrm{B}$ cells. We observed that $\mathrm{Mn}^{2+}$ but not $\mathrm{Mg}^{2+}$ or $\mathrm{Ca}^{2+}$, inhibited cell growth and induced apoptosis of activated tonsilar $B$ cells, Epstein Barr virus (EBV)-negative Burkitt's lymphoma cell lines (BL-CL) and EBV-transformed $B$ cell lines (EBV-BCL). In the same conditions, no apoptosis was observed in U937, a monoblastic cell line. Induction of B cell apoptosis by $\mathrm{Mn}^{2+}$ was time-and dose-dependent. The cell permeable tripeptide inhibitor of ICE family cysteine proteases, zVAD-fmk, suppressed $\mathrm{Mn}^{2+}$-induced apoptosis. Furthermore, $\mathbf{M n}^{2+}$ triggered the activation of interleukin-1 $\beta$ converting enzyme (ICE/caspase 1), followed by the activation of CPP32/Yama/Apopain/caspase-3. In addition, poly(ADP-ribose) polymerase (PARP), a cellular substrate for CPP32 protease was degraded to generate apoptotic fragments in $\mathrm{Mn}^{2+}$-treated $\mathrm{B}$ cell lines. The inhibitor, zVADfmk suppressed $\mathrm{Mn}^{2+}$-triggered CPP32 activation and PARP cleavage and apoptosis. These results indicate that the activation of caspase family proteases is required for the apoptotic process induced by $\mathrm{Mn}^{2+}$ treatment of $\mathrm{B}$ cells. While the caspase-1 inhibitor YVAD was unable to block apoptosis, the caspase-3 specific inhibitor DEVD-cmk, partially inhibited $\mathrm{Mn}^{2+}$-induced CPP32 activation, PARP cleavage and apoptosis of cells. Moreover, $\mathrm{Bcl}-2$ overexpression in $\mathrm{BL}-\mathrm{CL}$ effectively protected cells from apoptosis and cell death induced by manganese. This is the first report showing the involvement of $\mathrm{Mn}^{2+}$ in the regulation of $B$ lymphocyte death presumably via a caspase-dependent process with a deathprotective effect of Bcl-2.
Keywords: Apoptosis; manganese; human B cells; caspase

Abbreviations: $\mathrm{PI}$, propidium iodide; DMSO, dimethyl sulfoxide; PFA, paraformaldehyde; ICE, interleukin-1 $\beta$-converting enzyme; PARP, poly-(ADP-ribose) polymerase; zVAD-fmk, Z-Val-Ala-DLAsp-fluoromethylketone; DEVD-cmk, Asp-Glu-Val-Asp-chloromethylketone; BL-CL, Epstein Barr virus negative Burkitt's lymphoma cell lines; EBV-BCL, Epstein Barr virus (EBV)transformed $B$ cell lines; ROS, reactive oxygen species; SAC, staphylococcus aureus cowan 1 strain (pansorbin)

\section{Introduction}

Apoptosis or programmed cell death is a physiological process leading to methodical destruction of the cell. This phenomenon is observed in various situations and is critical during organ development and tissue homeostasis. ${ }^{1,2}$ It can be initiated by several physiological and pathological processes or in response to chemical or physical treatments. ${ }^{3}$ Morphologically, apoptosis is characterized by loss of cell volume, plasma membrane bleeding, cell shrinkage, expression of phosphatidylserine on the outer leaflet of the cell membrane, chromatin condensation and DNA fragmentation into oligo-nucleosome-sized fragments. ${ }^{4,5}$

Apoptosis plays a key role in the maintenance of cell population homeostasis including B lymphocytes. ${ }^{6}$ Diverse stimuli, including cytokines, soluble factors, oxidative stress, drugs and ions can modulate lymphocyte activation and lead to apoptosis (reviewed ${ }^{7}{ }^{7}$ ). Apoptosis of B cells can be spontaneous ${ }^{8}$ or it can be induced by several mechanisms: Ag receptor cross-linking, ${ }^{9-11}$ APO-1 (CD95) ligation, ${ }^{12}$ increase of the intracellular $\mathrm{Ca}^{2+}$ by ionomycin, ${ }^{13}$ cytokines such as IL-10 and IL-5 $5^{14,15}$ and chemotherapic agents. ${ }^{16,17}$ Survival factors, particularly interleukins IL-2, IL-4, IL-6, IL-8, IL13, INF- $\alpha$ and INF- $\gamma,{ }^{18-24}$ and CD6 and CD40 antigens ${ }^{25,26}$ prevent apoptosis of B leukemia cells. Among these stimuli, CD40 increases the survival of B cells by upregulating the expression of bcl-2 protein. ${ }^{27}$ There is accumulating evidence suggesting that members of the ICE/CED-3 protease family are involved in the execution phase of apoptosis. ${ }^{28,29}$ These cysteine-related proteases, named caspases, are synthesized as inactive proenzymes which are activated by cleavage at specific aspartate sites. Activation of the caspase cascade results in changes in the plasma-membrane, mitochondria and nucleus. ${ }^{7}$ Apoptosis is a multistep process involving the sequential activation of different caspases. In the Fas activation system, such a multistep process has been proposed: caspase-8 initiates the activation of caspase- 1 which potentiates the activity of the protease machinery including caspase- 3 and caspase$7^{30}$

Various lines of evidence suggest that divalent cations are involved in the regulation of apoptosis in mammalian 
cells. For example, depletion of $\mathrm{Zn}^{2+}$ enhances apoptosis $^{31}$ while its supplementation inhibits internucleosomal fragmentation and apoptosis in vitro and in vivo. ${ }^{32,33}$ Recent studies have shown the contribution of $\mathrm{Zn}^{2+}$ to the inhibition of caspase-3 activity. ${ }^{34,35}$ Another divalent cation $\mathrm{Mn}^{2+}$ down-regulates apoptosis activation in some cell types and up-regulates it in others. $\mathrm{Mn}^{2+}$ at low concentration $\left(<10^{-7} \mathrm{M}\right)$, interfering with oxidative products, acts as an antioxidant and inhibits the apoptosis of neutrophils. ${ }^{36,37}$ In contrast, at high concentration (>0.5 mM), $\mathrm{Mn}^{2+}$ induces apoptosis in cultured cerebellar granular neurons and in PC12 cells. ${ }^{38}$ Thus $\mathrm{Mn}^{2+}$ appears to be able to counteract oxidative stress and modulate apoptosis depending on the cell type and concentration used.

In this report we show that $100 \mu \mathrm{M} \mathrm{Mn}^{2+}$ suppresses proliferation and induces apoptosis of human B cells. This effect was observed with normal tonsillar B cells and cell lines such as EBV-negative Burkitt lymphoma B cells and EBV-transformed $\mathrm{B}$ cells. $\mathrm{Mn}^{2+}$-induction of apoptosis was dose-dependent and triggered the activation of ICE followed by CPP32 activation and in vivo cleavage of poly (ADP-ribose) polymerase (PARP). Our results suggest that $\mathrm{Mn}^{2+}$ initiates a death signaling caspase cascade leading to B cell apoptosis.

\section{Results}

\section{Manganese induces growth inhibition and apoptosis in human $B$ cells}

To examine the effect of divalent cations on $B$ lymphocyte proliferation and apoptosis, we cultured $B$ cells in the presence of different cations. The data in Figure 1 indicate that $\mathrm{Mn}^{2+}$ but not $\mathrm{Mg}^{2+}$ dosedependently inhibited the proliferation of SAC-activated normal $B$ cells and DN1 EBV-BCL. The growth inhibition of tonsillar $B$ cells and the DN1 cell line was almost complete at $100 \mu \mathrm{M} \mathrm{MnCl}_{2}$. We subsequently investigated whether $\mathrm{Mn}^{2+}$-mediated growth inhibition correlated with an induction of apoptosis. We treated BL41 BL-CL with various cations for $48 \mathrm{~h}$ and apoptosis was determined by three different methods to assess whether the cell death observed was indeed apoptosis (Figure 2). Analysis of cell dot-blot light scatter profiles by flow cytometry showed that $100 \mu \mathrm{M} \mathrm{MnCl} 2$ induced a cell shrinkage (63 vs $19 \%$ in control cells, Figure 2A) whereas $\mathrm{MgCl}_{2}$ at the same concentration had no effect. We also assessed chromatin condensation in the presence and absence of $\mathrm{Mn}^{2+}$ following the hypodiploid DNA peak by flow-cytometry: $35 \%$ of the nuclei in Mntreated cells but only $2-3 \%$ in control and Mg-treated cells were hypodiploid (Figure $2 \mathrm{~B}$ ). Finally, $\mathrm{MnCl}_{2}$ induced phosphatidylserine expression on the outer leaflet of the cells (67 vs $15 \%$ in control or Mg-treated cells; Figure 2C). To establish more apoptotic criteria in $\mathrm{Mn}^{2+}$-induced programmed cell death, we next analyzed other morphologic nuclear manifestation of apoptosis: nuclear fragmentation and internucleosomal DNA cleavage. Figure 3 shows the typical condensed and fragmented nuclear

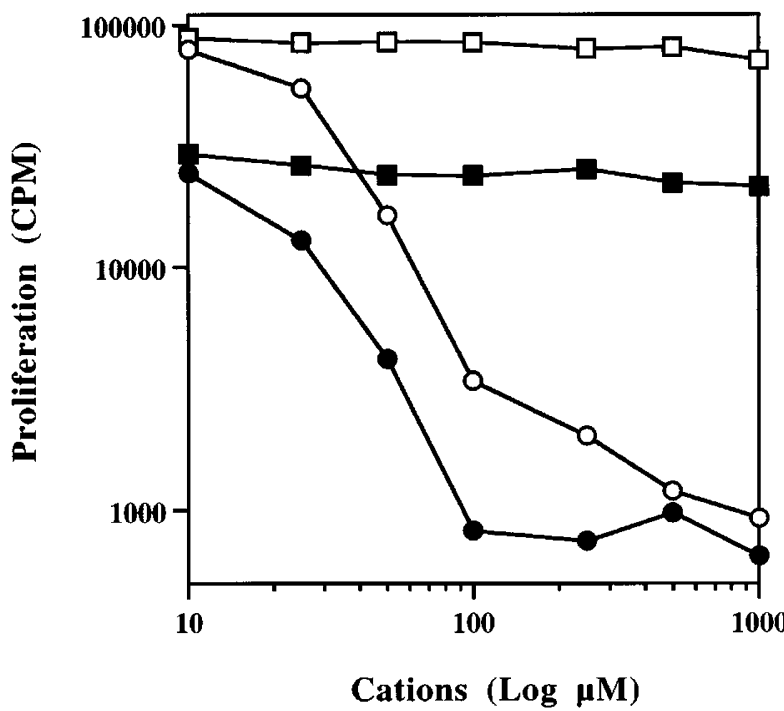

Figure 1 Effects of $\mathrm{Mn}^{2+}$ and $\mathrm{Mg}^{2+}$ on proliferation of normal $\mathrm{B}$ cells and the EBV-B cell line. Tonsillar B cells $\left(2 \times 10^{5}\right.$ per well; filled symbols $)$ stimulated with $1 / 10000$ SAC were cultured for $72 \mathrm{~h}$ and DN1 cell line $\left(5 \times 10^{4}\right.$ per well; open symbols) for $48 \mathrm{~h}$ at $37^{\circ} \mathrm{C}$ in the presence of various concentrations of divalent cations $\left(\mathrm{Mn}^{2+}\right.$, circle and $\mathrm{Mg}^{2+}$, square). $\left[{ }^{3} \mathrm{H}\right]$ thymidine incorporation was assessed during the last $6 \mathrm{~h}$ of culture. All determinations were made in triplicate. The data shown are representative of three separate experiments

morphology accompanied by the characteristic ladder pattern of DNA fragmentation of BL41 cells undergoing apoptosis after $48 \mathrm{~h}$ treatment with $100 \mu \mathrm{M} \mathrm{MnCl}_{2}$. Similar results were observed with other cell lines as DN1 or Ramos (data not shown). Thus, inhibition of human B cell proliferation by $\mathrm{Mn}^{2+}$ is clearly associated with an apoptotic process.

Apoptosis of DN1 cells induced by $\mathrm{Mn}^{2+}$ was doseand time-dependent as detected by flow cytometric analysis of hypodiploid nuclei (Figure 4A and B). Treatment of DN1 EBV-BCL with $\mathrm{MnCl}_{2} 48 \mathrm{~h}$ induced apoptosis with maximum effect at doses $(100-500 \mu \mathrm{M})$ close to those giving complete growth inhibition. $\mathrm{MnCl}_{2}$ induced apoptosis was first observed at $15 \mathrm{~h}$ and reached a plateau at $24 \mathrm{~h}$.

We next analyzed the effect of $\mathrm{Mn}^{2+}$ on a panel of seven human $B$ cell lines, tonsillar $B$ cells and a monoblastic cell line U937 (Table 1). In BL-CL (BL41, Ramos, CA46 Raji and Daudi), EBV-BCL (DN1 and GL1) and normal B cells, $\mathrm{Mn}^{2+}(250 \mu \mathrm{M})$ inhibited growth, decreased cell viability and induced apoptosis at $48 \mathrm{~h}$. In contrast, $\mathrm{Mn}^{2+}$ had no effect on proliferation or apoptosis of the monoblastic cell line U937.

\section{Apoptosis triggered by $\mathrm{Mn}^{2+}$ involves activation of ICE, CPP32 and cleavage of PARP}

Activation of the cascade of proteolytic caspases is a pathway of apoptosis in diverse biological systems. Members of the ICE caspase family are synthesized as proforms, which are proteolytically cleaved and activated during apoptosis. We investigated whether caspases, 
A
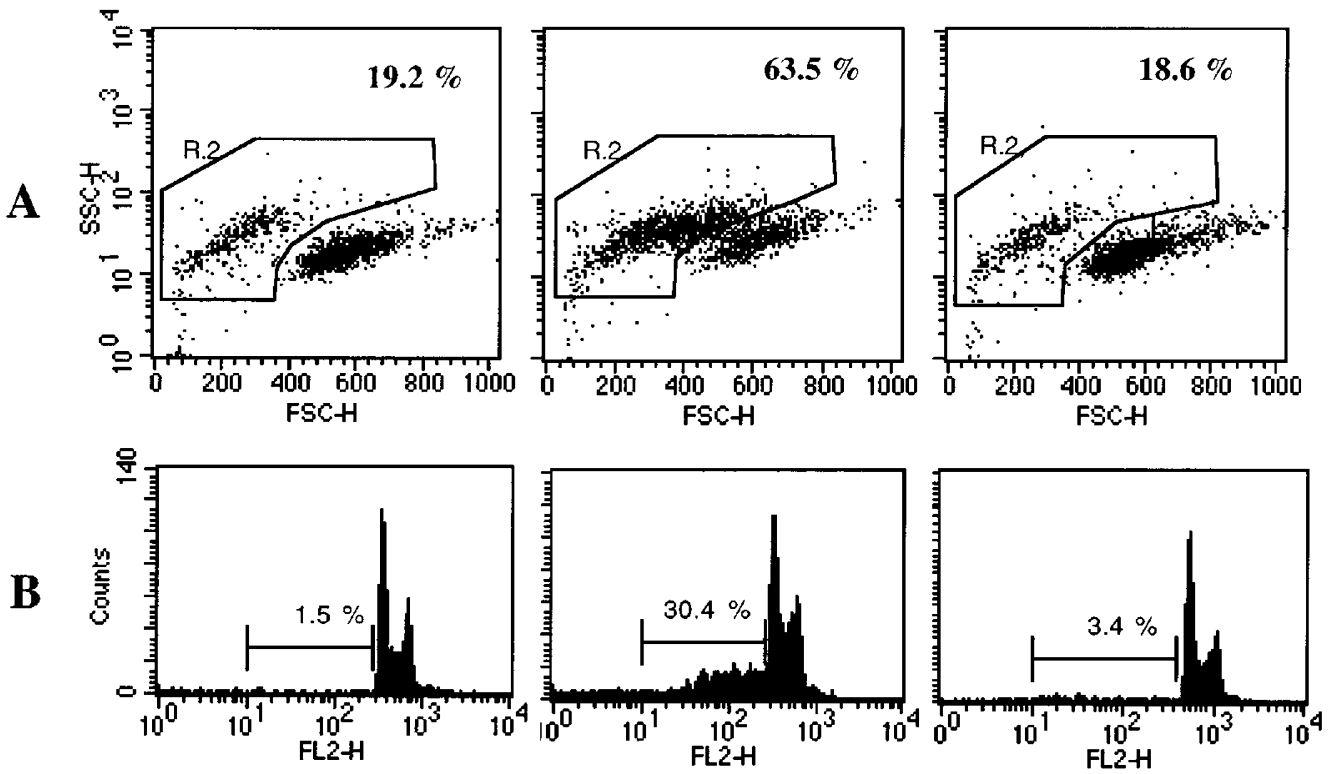

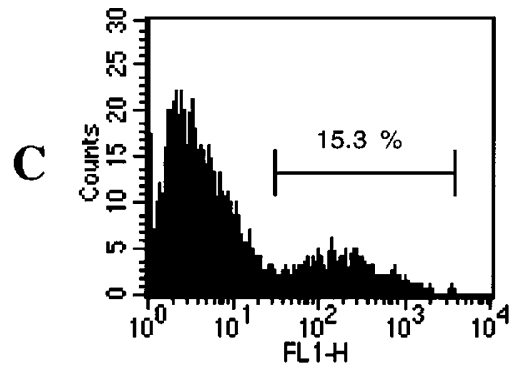

$(-)$

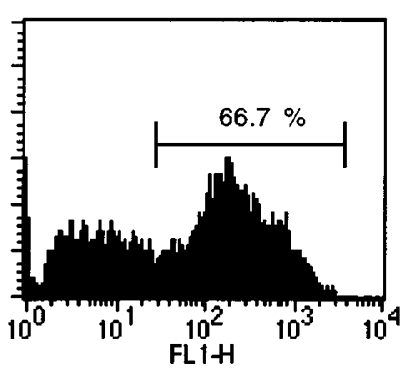

( Mn )

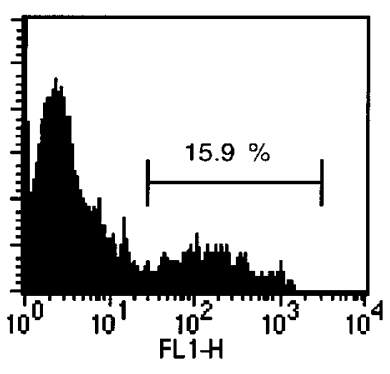

( Mg)

Figure 2 Apoptosis analysis of BL41 cells treated with $\mathrm{Mn}^{2+}$ and $\mathrm{Mg}^{2+}$. Cells were cultured for $48 \mathrm{~h}$ without (-) or in the presence of $\mathrm{MnCl}_{2}(100 \mu \mathrm{M})(\mathrm{Mn})$, or $\mathrm{MgCl}_{2}(100 \mu \mathrm{M})(\mathrm{Mg})$. Cells were analyzed by flow cytometry. (A) Apoptotic cells having a relatively high side-scatter (SSC) and a low forward-scatter (FSC) properties were enumerated as a percentage of total population. (B) Cell nuclei were stained with PI and the hypodiploid DNA peak corresponding to apoptotic nuclei was quantified. (C) Cells were stained with Annexine-V-FITC and apoptotic cells having phosphatidylserine on the outer leaflet of the cell membrane were quantified. These data represent three independent experiments

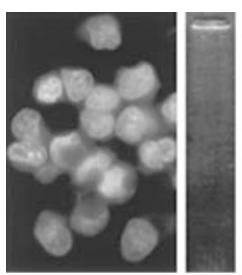

Control

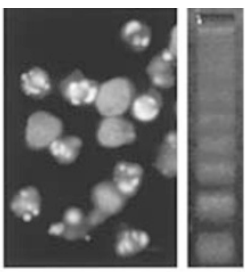

$\mathrm{MnCl2}$

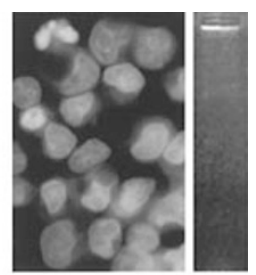

$\mathrm{MgCl} 2$
Figure 3 Nuclear morphology and internucleosomal DNA cleavage in BL41 cells treated with $\mathrm{Mn}^{2+}$ and $\mathrm{Mg}^{2+}$. Cells were cultured for $48 \mathrm{~h}$ with $100 \mu \mathrm{M}$ $\mathrm{MnCl}_{2}$ or $\mathrm{MgCl}_{2}$. Nuclear DNA of cells was stained with DAPI and subsequently analyzed under a fluorescence microscope. DNA fragments were analyzed as described in Materials and Methods

particularly caspase-1/ICE and caspase-3/CPP32, which are highly expressed in cell lines of lymphocytic origin, are components of the $\mathrm{Mn}^{2+}$-triggered pathway leading to apoptosis in the BL41 cell line. BL41 cells were treated with $100 \mu \mathrm{M} \mathrm{MnCl}_{2}$ and harvested at various times during the treatment (Figure 5). Each sample was tested for active caspases by Western blotting with appropriate specific antibodies. Processing of ICE was first detected as the appearance of $\mathrm{p} 10$ fragment after $30 \mathrm{~min}$ with its disappearance after $48 \mathrm{~h}$ (Figure 5A). We next analyzed the expression of CPP32 (Figure 5B). Western blot analysis showed that CPP32 on p17 and p23 subunits appeared after $24 \mathrm{~h}$ of stimulation. The p23 fragment (also referred to as p19 in the literature) appeared after $24 \mathrm{~h}$ with a decrease after $48 \mathrm{~h}$. The amount of $\mathrm{p} 17$ subunit was maximal $48 \mathrm{~h}$ after induction. These results suggest that p17 fragment may be a product of p23 proteolysis. ${ }^{39}$ These data show that apoptosis of $\mathrm{B}$ cells induced by $\mathrm{Mn}^{2+}$ is associated with activation of ICE and CPP32. These activations are sequential: ICE is processed first giving the characteristic p10 activated subunit after $30 \mathrm{~min}$ of incubation; CPP32 is then activated as shown by the appearance of the p23-p17 doublet after $24 \mathrm{~h}$ coinciding with the detection of apoptosis. 


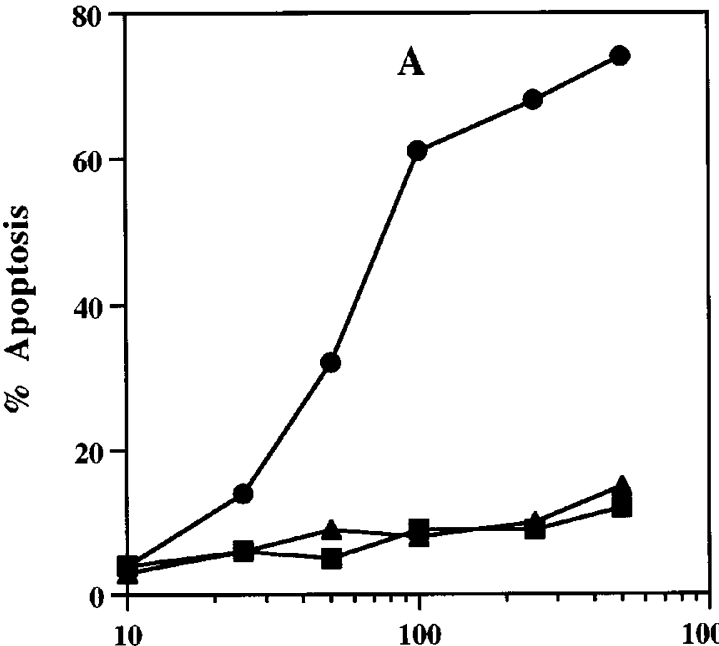

Cations $(\log \mu \mathrm{M})$

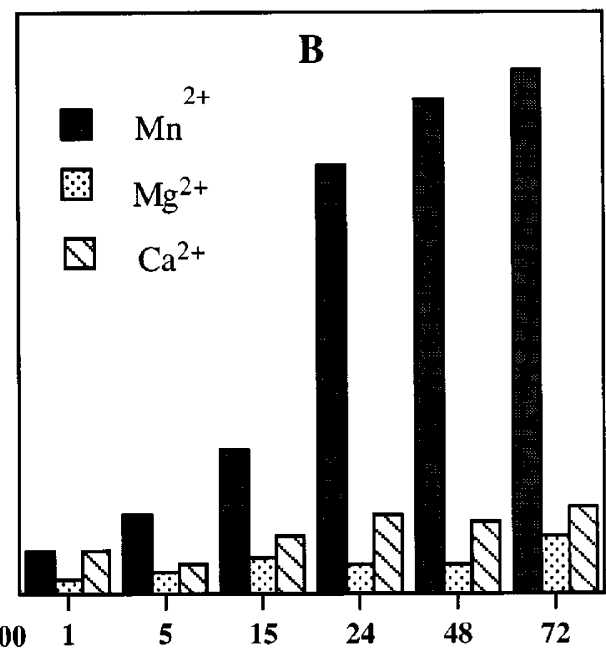

Time (hours)

Figure 4 Time course and dose-dependent effect of divalent cations on B cell apoptosis. (A) DN1 cells $\left(5 \times 10^{5}\right.$ per ml) were incubated with medium alone or exposed to one of a series of concentrations of $\mathrm{Mn}^{2+}(\mathbf{O}), \mathrm{Mg}^{2+}(\mathbf{\square})$ or $\mathrm{Ca}^{2+}(\mathbf{A})$ and hypodiploid nuclei were evaluated by cytometry after lysis in hypotonic propidium iodide. (B) Time-course experiments of apoptosis induced by $\mathrm{Mn}^{2+}, \mathrm{Mg}^{2+}$ and $\mathrm{Ca}^{2+}(250 \mu \mathrm{M})$ in DN1 cells. Cations-induced apoptosis was evaluated as described in Materials and Methods. Data are representative of four independent experiments

Table 1 Induction of apoptosis and growth inhibition by $\mathrm{Mn}^{2+}$ in various human B cells

\begin{tabular}{lccc}
\hline & $\begin{array}{c}\text { Inhibition of } \\
\text { proliferation } \\
\text { (\%) }\end{array}$ & $\begin{array}{c}\text { Viability } \\
\text { (\%) }\end{array}$ & $\begin{array}{c}\text { Apoptosis } \\
\text { (\%) }\end{array}$ \\
\hline EBV-B cell line & & & \\
GL1 & $87 \pm 6.5$ & 9 & $41 \pm 3.5$ \\
$\quad$ DN1 & $97 \pm 2.5$ & 3 & $59.5 \pm 14.8$ \\
Burkitt lymphoma & & & \\
$\quad$ BL41 & $95 \pm 5.1$ & 7 & $67.5 \pm 6.4$ \\
Ramos & $97.3 \pm 4.6$ & 5 & $60 \pm 8.5$ \\
CA46 & $90.6 \pm 4.1$ & 8 & $49 \pm 4.2$ \\
Raji & $95.6 \pm 2.1$ & 6 & $49 \pm 4.6$ \\
Daudi & $92 \pm 4$ & 10 & $\mathrm{ND}$ \\
& & & \\
Tonsillar B cells & $98.7 \pm 1.1$ & 3 & $71 \pm 4.2$ \\
U937 (monoblastic cell line) & $19.3 \pm 3.8$ & 75 & $11.5 \pm 4.9$ \\
\hline
\end{tabular}

All cell lines were cultured for $24 \mathrm{~h}$ (apoptosis) or $48 \mathrm{~h}$ (proliferation) and tonsillar B cells were stimulated by $1 / 10000$ SAC for $24 \mathrm{~h}$ (apoptosis) and $72 \mathrm{~h}$ (proliferation) in the presence of $250 \mu \mathrm{M} \mathrm{MnCl}_{2}$ or in medium alone as described in Figure 1. Cell viability was measured by trypan blue exclusion after $24 \mathrm{~h}$. Values are means \pm S.E.M. of three experiments. The percentage of apoptosis was calculated as described in Materials and Methods. ND, not done

To confirm that $\mathrm{Mn}^{2+}$ triggers activation of CPP32, we investigated the expression of PARP, one of the endogenous substrates of CPP32. PARP is a 110-kDa original molecule and is proteolyzed by caspase- 3 to give two apoptotic fragments of $87-k D a$ and $24-k D a$. We examined the cleavage of PARP in $\mathrm{Mn}^{2+}$-treated BL41 cells by Western blotting using anti-PARP polyclonal antibody which recognizes both the 110-kDa and 87-kDa polypeptides (Figure 5C). PARP breakdown, with complete disappearance of the 110 $\mathrm{kDa}$ form, was observed after $24 \mathrm{~h}$ in cells treated with $100 \mu \mathrm{M} \mathrm{MnCl}_{2}$ but not in $\mathrm{MgCl}_{2}$ treated cells.

\section{Apoptosis and PARP cleavage induced by $\mathrm{Mn}^{2+}$ is inhibited by the tripeptide inhibitor of the ICE-like protein zVAD-fmk}

The above results clearly indicated that CPP32 is activated in $\mathrm{B}$ cells in response to $\mathrm{Mn}^{2+}$ treatment. To test whether the activation of caspase-3 and PARP cleavage is required for the apoptotic process in $\mathrm{Mn}^{2+}$ treated B cells, we examined the effects of zVAD-fmk, a broad inhibitor of the ICE family of cysteine proteases, and DEVD-cmk, a more specific inhibitor of the caspase-3 (CCP32) family of cysteine proteases. Apoptosis and PARP cleavage induced by $\mathrm{Mn}$ in BL41 cells were followed. After $48 \mathrm{~h}$ of culture with Mn, zVAD-fmk (10$100 \mu \mathrm{M})$ induced a dose-dependent decrease in the percentage of apoptotic BL41 cells (Figure 6). This inhibition correlated with a decrease in the expression of $87-\mathrm{kDa}$ fragment and with a complete inhibition of PARP proteolysis at $25 \mu \mathrm{M}$ zVAD-fmk. In contrast, DEVD-cmk partially inhibited $\mathrm{Mn}^{2+}$-induced apoptosis and PARP cleavage even at the high concentration of $100 \mu \mathrm{M}$. Experiments of cell viability measured by trypan blue exclusion showed that $100 \mu \mathrm{M}$ zVAD-fmk was also able to almost completely block cell death (85\% inhibition) induced by $48 \mathrm{~h}$ manganese treatment of BL41 cells (data not shown). These results indicate that apoptosis induced by $\mathrm{Mn}^{2+}$ is more efficiently blocked by the broad spectrum caspase inhibitor than by the relatively caspase3 specific inhibitor DEVD-cmk. Presumably, other members of the caspase family, sensitive to zVAD-fmk, are involved in the apoptotic process. In conclusion, our results indicate that $\mathrm{Mn}^{2+}$-induced apoptosis of $\mathrm{BL} 41$ cell involves the sequential activation of several caspases leading to a caspase-dependent cell death process. 


\section{Overexpression of Bcl-2 inhibited manganese- mediated apoptosis}

The $\mathrm{Bcl}-2$ protein is a potent inhibitor of both apoptosis and caspase- 3 activation in different cells including Burkitt cell

A

ICE

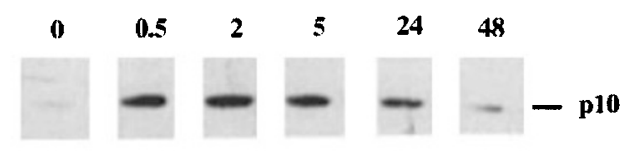

B

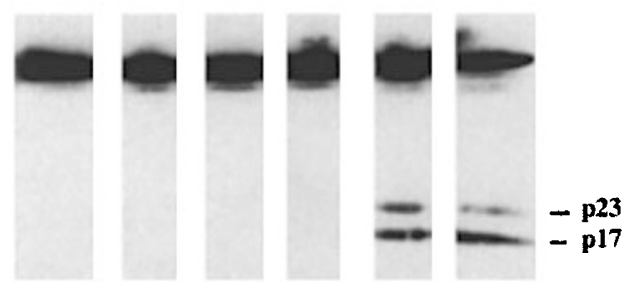

(-) Mn Mg

\section{C}

PARP

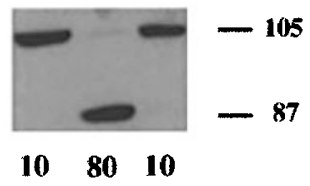

Figure 5 Analysis of caspases and PARP expression in stimulated BL41 cells. (A and B) Cells were cultured with $\mathrm{MnCl}_{2}(100 \mu \mathrm{M})$ and the activated fragment of ICE, the $p 10$ subunit (A) and CPP32, the p23 and p17 subunits (B) were analyzed after various times $(0,0.5,2,5,24,48 \mathrm{~h})$ by Western blotting. The membrane from ICE analysis was stripped and reprobed for CPP32 detection. After $48 \mathrm{~h}$ of $\mathrm{Mn}^{2+}$ treatment, apoptotic cells were quantified by flow cytometric analysis of dot-blot light scatter profiles ( $9 \%$ of apoptosis in control and $59 \%$ in $\mathrm{MnCl}_{2}$-stimulated cells). (C) Cells were cultured for $24 \mathrm{~h}$ in medium alone or with $100 \mu \mathrm{M} \mathrm{MnCl}_{2}$ or $100 \mu \mathrm{M} \mathrm{MgCl}_{2}$ and PARP cleavage was analyzed by Western blotting with specific anti-PARP antibodies. The proportion of apoptotic cells in each sample was quantified after $48 \mathrm{~h}$ by flow cytometric analysis of dot-blot light scatter profiles
ZVAD-fmk

\begin{tabular}{lllllllllll}
\hline 0 & 1 & 5 & 10 & 25 & 50 & 100 & & & 100 & $\mu M$
\end{tabular}

\section{$(-)$}

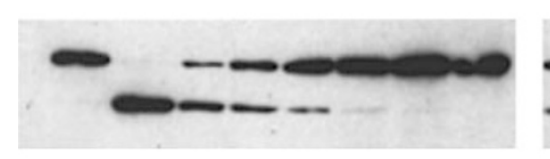

17

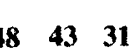

$\begin{array}{lll}31 & 28\end{array}$
1768

\begin{abstract}
57. 48
\end{abstract}

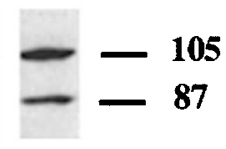

50 Apoptosis \%
Figure 6 Inhibition of $\mathrm{Mn}^{2+}$-induced apoptosis and PARP cleavage in BL41 cells by zVAD-fmk, a tripeptide inhibitor of ICE like protein. Cells were cultured for $48 \mathrm{~h}$ in the absence $(-)$ or in the presence of $100 \mu \mathrm{M} \mathrm{MnCl}_{2}$ and various concentrations of zVAD-fmk $(0,1,5,10,25,50,100 \mu \mathrm{M})$ or DEVD-cmk $(100 \mu \mathrm{M})$. The cleavage of PARP was determined by immunoblotting and the amount of apoptotic cells in each sample evaluated after $48 \mathrm{~h}$ of stimulation by flow cytometry. Cell morphology established by flow cytometry measurement of shrunken cells was correlated to cell viability measured by trypan blue exclusion lines. To better understand the apoptotic pathways triggered by manganese, we further investigated whether overexpression of the proto-oncogene Bcl2 in BL-CL Ramos could counteract $\mathrm{Mn}$-induced apoptosis. We transfected Ramos cells with the human $\mathrm{Bcl}-2$ gene (Ra-bcl2) and isolated a subclone based on its $\mathrm{Bcl}-2$ overexpression. FACS analysis revealed the overexpression of $\mathrm{Bcl}-2$ in stable Ramos-Bcl-2 subclone in contrast to Ramos control cells (Figure 7A). Ramos and Ramos-Bcl-2 cells were treated with different concentrations of manganese and viability and features of apoptosis were analyzed. We observed in Figure 7B that overexpression of $\mathrm{Bcl}-2$ completely rescued $\mathrm{Ra}-\mathrm{Bcl}-2$ cell viability (trypan-excluding) even at high manganese concentrations (up to $250 \mu \mathrm{M}$ ). Other apoptotic features, induced with

A

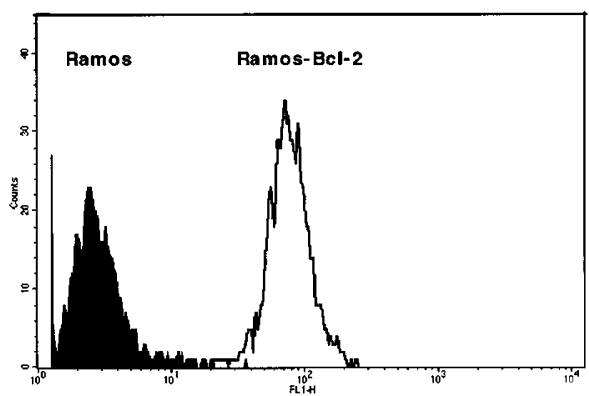

B
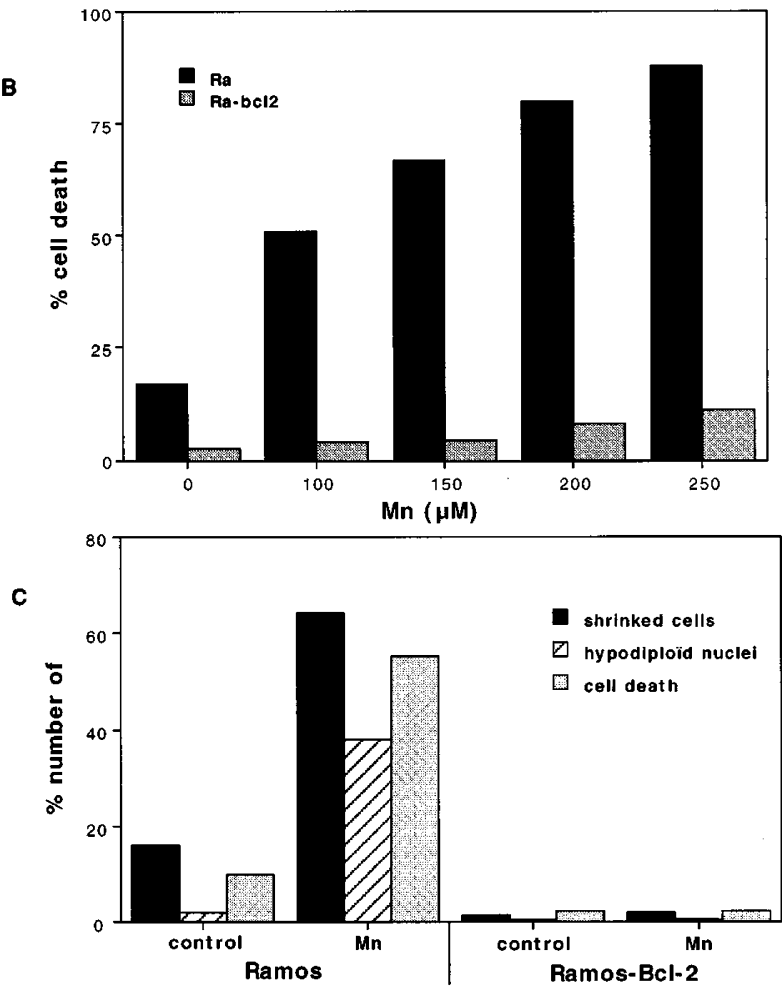

Figure 7 Overexpression of $\mathrm{Bcl}-2$ counteracts $\mathrm{Mn}^{2+}$-induced apoptosis and cell death. (A) Overexpression of $\mathrm{Bcl}-2$ was quantified in Ramos and Ramos$\mathrm{Bcl}-2$ cells by flow cytometric analysis using FITC-labelled anti-human Bcl-2 monoclonal antibody. (B) Ramos and Ramos-Bcl-2 cells were cultured with various concentrations of $\mathrm{MnCl}_{2}$ for $48 \mathrm{~h}$ and viable cells were counted using trypan blue exclusion. (C) After $48 \mathrm{~h}$ of treatment with $100 \mu \mathrm{M} \mathrm{MnCl}_{2}$, cells were analyzed for cell shrinkage, chromatin condensation and viability. Here is shown a representative experiment done in triplicate 
$100 \mu \mathrm{M} \mathrm{MnCl}$, including cell shrinkage and chromatin condensation, were also reversed in Ramos cells overexpressing $\mathrm{Bcl}-2$ as compared to Ramos control cells. These results indicate that overexpression of $\mathrm{Bcl}-2$ protects Ramos cells from Mn-mediated apoptosis and cell death and that manganese activates an apoptotic pathway sensitive to $\mathrm{Bcl}-2$ regulation.

\section{Discussion}

In this report, we provide the first demonstration that the divalent cation $\mathrm{Mn}^{2+}$ induces growth inhibition and cell death of human B cells (Figure 1). Other cations including $\mathrm{Mg}^{2+}$ and $\mathrm{Ca}^{2+}$ had no effect on $\mathrm{B}$ cell apoptosis. $\mathrm{Mn}^{2+}$ effect was observed on normal and various malignant $B$ cells. In all cases (normal-activated B cells, BL-CL and EBV-BCL), $\mathrm{Mn}^{2+}$ blocked the proliferation and induced apoptosis of $\mathrm{B}$ cells (Table 1). This $\mathrm{Mn}^{2+}$-mediated cell death displayed characteristic features of apoptosis: cell shrinkage, chromatin condensation, expression of phosphatidylserine on the outer leaflet of the cell, nuclear fragmentation and DNA laddering (Figures 2 and 3). To our knowledge, this is the first report of the involvement of $\mathrm{Mn}^{2+}$ in the apoptosis of $\mathrm{B}$ cells.

The mechanisms by which $\mathrm{Mn}^{2+}$ mediates $\mathrm{B}$ cell apoptosis remain unclear. The neurotoxic effect of $\mathrm{Mn}^{2+}$ associated with the formation of reactive oxygen species ${ }^{40}$ and the subsequent oxidative stress has been suggested to be responsible for neural damage ${ }^{41}$ and apoptosis of PC12 cells. ${ }^{38} \mathrm{~A}$ recent report has shown that U937 TNF-induced cell death is blocked by $\mathrm{N}$-acetylcysteine, implying the involvement of ROS in apoptosis. ${ }^{42}$ We observed that $\mathrm{Mn}^{2+}$ treatment had no effect on the proliferation or apoptosis of the monocyte cell line U937. Moreover, the addition of antioxidants ( $\mathrm{N}$-acetylcysteine, L-NAME or catalase) did not prevent the apoptosis of $\mathrm{B}$ cells after $\mathrm{Mn}^{2+}$ treatment. Moreover, $\mathrm{Mn}^{2+}$ pretreatment of SAC- or PMA-stimulated normal B cells or EBV-BCL completely abolished the generation of $\mathrm{O}^{2-}$ (data not shown). Thus, these observations appear to exclude the role of $\mathrm{ROS}$ in $\mathrm{Mn}^{2+}$ induced B cell apoptosis.

Activation by divalent cations and cationic polypeptides has been extensively studied for the insulin ${ }^{43,44}$ and EGF ${ }^{45}$ receptors. Cations activate protein tyrosine kinases by facilitating kinase-kinase interactions thereby resulting in an increase of kinase activity. In fact, $\mathrm{Mn}^{2+}$ strongly enhances EGF receptor kinase activity by promoting the aggregation of kinase domains of the receptor, thus mimicking the effect of an effector ligand. ${ }^{46}$ Similar observations have been reported for the insulin receptor. ${ }^{47}$ The putative target molecules activated by divalent cation $\mathrm{Mn}^{2+}$ remain to be identified. Possibly kinases, associated with cell surface receptors and/or involved in the regulation of apoptosis pathway, could be activated by $\mathrm{Mn}^{2+}$. We previously reported $^{9}$ that apoptosis triggered through $\mathrm{AgR}$ or its associated surface molecules, CD19 or CD22, was dependent on the degree of cross-linking of these receptors. Moreover, the appearance of apoptotic features and the kinetics of ICE and CPP32 activation after AgR cross-linking in $B$ cells are similar to those observed after $\mathrm{Mn}^{2+}$ treatement (A. Vazquez et al, manuscript in preparation). In addition, z-VAD and DEVD inhibited apoptosis and caspase-3 processing mediated by $\mathrm{AgR}$ cross linking or $\mathrm{Mn}^{2+}$. These results suggested that $\mathrm{Mn}^{2+}$ mediated apoptosis in B cells could involve surface receptor aggregation leading to kinase activation. However, in our experimental conditions, $\mathrm{Mn}^{2+}$ did not trigger major tyrosine kinase activation even after $1 \mathrm{~h}$ of stimulation, when ICE was already activated (data not shown). This does not exclude the possibility that $\mathrm{Mn}^{2+}$ mobilized other kinases involved in AgR-triggered apoptotic pathway. Work is in progress to verify this hypothesis and try to characterize the potent targets of manganese.

To elucidate the apoptotic pathway following $\mathrm{Mn}^{2+}$ treatment of $\mathrm{B}$ cells, we attempted to block cell death with the inhibitor zVAD-fmk (a broad spectrum caspase inhibitor). ZVAD-fmk blocked morphological changes (Figure 6) and disorganization of plasma membrane phospholipids but not cell proliferation inhibition associated with $\mathrm{Mn}^{2+}$-induced apoptosis (data not shown). This finding suggests that $\mathrm{Mn}^{2+}$ growth inhibition does not involve the ICE family protease family. It is possible that $\mathrm{Mn}^{2+}$. mediated inhibition of cell proliferation and induction of apoptosis involve distant activation pathways. Another interpretation could be that high intracellular levels of $\mathrm{Mn}^{2+}$ causes irreversible damage to the cell, which usually triggers the apoptotic pathway for efficient cell destruction and removal. After blocking the caspases, the apoptotic manifestations of cell death are suppressed, yet the cell is damaged beyond repair and ultimately dies of necrosis. To investigate the biochemical mechanism by which $\mathrm{Mn}^{2+}$ induces B cell apoptosis, we examined the activation and the processing of the caspase cascade. $\mathrm{Mn}^{2+}(100 \mu \mathrm{M})$ activated ICE then CPP32 in specific temporal sequence. This activation was characterized by the production of their catalytic subunits: p10 for ICE and the doublet p17-p23 for CPP32. ICE was activated during the first $30 \mathrm{~min}$ of treatment and CPP32 later, after $24 \mathrm{~h}$. Moreover, appearance of the CPP32 catalytic subunits P17 and p23 was associated in vivo by PARP cleavage, one of the CPP32 substrates (Figure 5). This cleavage (Figure 6) was completely inhibited by a caspase family inhibitor zVADfmk $(25 \mu \mathrm{M})$ and to a lesser extent by DEVD-cmk $(100 \mu \mathrm{M})$ a more restricted caspase-3 inhibitor. The same concentration of zVAD-fmk almost completely suppressed $\mathrm{Mn}^{2+}$ mediated apoptosis (80\% inhibition) whereas DEVD-cmk at doses up to $100 \mu \mathrm{M}$ partially blocked B cell death $(37 \%$ inhibition). These data demonstrate that $\mathrm{Mn}^{2+}$ activates the caspase pathway for inducing cell death. The remaining cleavage of PARP in DEVD pre-treated cells was probably due to caspases other than caspase- 3 also being able to cleave PARP in vivo albeit with a lower efficiency. ${ }^{48}$ The recruitment of this pathway might depend on a caspase, other than CPP32, and which is sensitive to zVAD-fmk but not to DEVD-cmk inhibitors. Finally, the induction of apoptosis and cell death by manganese was completely abolished in BL-CL Ramos which overexpress Bcl-2. Bcl-2 is an anti-apoptotic protein upregulated after stimulation by several physiological factors which increase the survival of $B$ cells. Like the germinal center B cells, Burkitt lymphoma $B$ cells which have a germinal center origin do not express 
the bcl-2 protein. After stimulation by anti-CD40 antibody, these cells upregulated bcl-2 protein and were more resistant against apoptosis. ${ }^{27}$ These findings indicate that manganese induces a caspase-dependent process of cell death in $B$ cells which can be negatively regulated by survival factors such as Bcl-2.

It is clear that divalent metal ions play a major role in the regulation of cellular apoptosis. For instance, $\mathrm{Zn}^{2+}$ influences the regulation of apoptosis in various cell types. Unlike $\mathrm{Mn}^{2+}, \mathrm{Zn}^{2+}$ prevents apoptosis in both in vitro and in vivo models. ${ }^{32,49,50} \mathrm{Ca}^{2+} / \mathrm{Mg}^{2+}$-endonucleases have been proposed as possible candidates for $\mathrm{Zn}^{2+}$ antiapoptotic activity. ${ }^{33,51}$ Caspase-3/CPP32 was identified as a target of $\mathrm{Zn}^{2+}$ inhibition in $\mathrm{T}$ cell apoptosis. ${ }^{34}$ Our study shows that $\mathrm{Mn}^{2+}$ triggers $\mathrm{B}$ cell apoptosis which is associated with the differential activation of caspase-1 and caspase-3. This observation supports the importance of divalent cations in the induction and/or regulation of programmed cell death of human B lymphocytes. Recently, investigators reported that low doses of arsenic trioxide, another heavy metal ion, could induce complete remissions in patients with acute promyelocytic leukemia who have relapsed after extensive prior therapy. ${ }^{52}$ Clinical responses were associated with induction of apoptosis through caspase activation. ${ }^{53}$ Arsenic trioxide affected only partially proliferation and did not induce apoptosis of $B$ lymphoma cell lines such as Raji and Daudi. ${ }^{54}$ The ability of manganese to induce cell death of $\mathrm{EBV}^{+}$- and $\mathrm{EBV}^{-}-\mathrm{B}$ cells such as Burkitt's lymphoma may be applied to other B-cell tumors (chronic lymphocytic leukemia and follicular non-Hodgkin's lymphomas). These observations could provide an experimental basis and a new approach for $\mathrm{B}$ cell tumor therapy.

\section{Materials and Methods}

\section{Reagents}

$\mathrm{MnCl}_{2}, \mathrm{MgCl}_{2}, \mathrm{CaCl}_{2}$ and DAPI (4,6-diamidino-2-phenylindole) were obtained from Sigma (St. Louis, MO, USA). Z-Val-Ala-DL-Aspfluoromethylketone (zVAD-fmk), a cell permeable irreversible tripeptide inhibitor of the ICE family of cysteine proteases and Z-Asp-GluVal-Asp-chloromethylketone (DEVD-cmk), a cell permeable inhibitor of the caspase 3 cysteine protease were supplied by Bachem Biochimie SARL (Voisin le Bretonneux, France). Stock solutions of zVAD-fmk and of DEVD-cmk, $100 \mathrm{mM}$ each in DMSO were kept at $-20^{\circ} \mathrm{C}$ and appropriate dilutions prepared immediately prior to use. SAC, staphylococcus aureus cowan 1 strain (pansorbin) was from Calbiochem (France Biochem).

\section{BL cell lines}

The Burkitt lymphoma cell line Ramos, BL41, Raji, CA46 and Daudi and the monoblastic leukemia line U937 were obtained from ATCC (Rockville, MD, USA). DN1 and GL1 B cell lines were obtained by EBV infection of normal $B$ cells in vitro as previously described. ${ }^{55}$

\section{Cell culture and bioassays}

BL cells were cultured in RPMI 1640 medium (Seromed, Biochrom, Berlin, Germany) supplemented with $1 \%$ glutamine, $1 \%$ antibiotic and
5\% fetal bovine serum (Gibco, Grand Island, NY, USA). B cell proliferation was studied in the presence of various concentrations of $\mathrm{MnCl}_{2}$ or $\mathrm{MgCl}_{2}$ in 96-well flat-bottom microtest plates (Falcon, Oxnard, CA, USA). Cells were cultured for 2 days and then pulsed with $\left[{ }^{3} \mathrm{H}\right]$ Thymidine $(0.5 \mu \mathrm{Ci}$ per well) (CEA, Saclay, France) for an additional $16 \mathrm{~h}$. The cells were then harvested and radioactivity counted. For cytometric analysis, BL cells were recovered at the end of treatment and the percentage of apoptotic cells was determined as described below.

\section{Cell transfection}

The pSFFV-bcl2-neo vector bearing the human bcl-2 cDNA was transfected into Ramos cells by electroporation and stable transfectant was isolated. After selection, overexpression of $\mathrm{Bcl} 2$ protein by Ramos-bcl-2 cells was verified by flow cytometry analysis using an anti-human $\mathrm{Bcl}-2$ monoclonal antibody FITC-labeled (DAKO A/S, Denmark).

\section{Determination of apoptosis}

$B$ cell apoptosis was detected first by cytometric analysis of dot-blot light scatter profiles. The cells $\left(10^{6}\right)$ were washed in PBS and resuspended in 1\% PFA (paraformaldehyde) in PBS. After $1 \mathrm{~h}$ of incubation at room temperature, apoptotic cells were analyzed for their dot-blot light scatter profile by flow cytometry using a FACScan flow cytometer (Becton-Dickinson, Mountain View, CA, USA). Apoptotic cells having relatively high light side-scatter and a low light forwardscatter properties were enumerated as a percentage of the total population.

For the DNA labeling flow cytometric analysis, hypodiploid DNA was analyzed by flow-cytometry as previously described. ${ }^{56}$ Briefly, cells $\left(10^{6}\right)$ were washed in PBS and resuspended in $1 \mathrm{ml}$ hypotonic fluorochrome solution ( $50 \mathrm{mg} \mathrm{ml}^{-1}$ propidium iodide in $0.1 \%$ sodium citrate plus $0.1 \%$ Triton X-100) (Sigma, St. Louis, MO, USA). Samples were incubated at room temperature for $1 \mathrm{~h}$ before flowcytometry analysis of PI fluorescence of individual nuclei using a FACScan flow cytometer (Becton-Dickinson, Mountain View, CA, USA) as described elsewhere. ${ }^{57}$ Cellular debris were excluded from analysis by raising the forward scatter threshold and the DNA content of the intact nuclei was registered on a logarithmic scale. Apoptotic cell nuclei having hypodiploid DNA emitting fluorescence in channels 10-200 were enumerated as a percentage of the total population. The percentage of $\mathrm{Mn}^{2+}$-induced apoptosis (Figure 3 and Table 1) was calculated as follows: (\% of hypodiploid nuclei in test sample $-\%$ of spontaneous hypodiploid nuclei $) /(1-\%$ of spontaneous hypodiploid nuclei ) $\times 100$.

Phosphatidylserine on the outer leaflet of the cells was also analyzed as a marker of apoptosis. Cells $\left(10^{6}\right)$ were washed in PBS and resuspended in incubation buffer (10 mM HEPES/NaOH, pH 7.4, $140 \mathrm{mM} \mathrm{NaCl}, 5 \mathrm{mM} \mathrm{CaCl}$ ) and Annexine-V-FITC (Boehringer Mannheim). After $15 \mathrm{~min}$ of incubation, the fluorescence emitted by cells was analyzed using a FACScan flow cytometer (Bectondickinson, Mountain View, CA, USA). Apoptotic cells having phosphatidylserine on the outer leaflet of the cell membrane and positively stained by annexine $\mathrm{V}$ were enumerated as a percentage of the total population.

Morphological assessment of nuclear fragmentation was determined microscopically. Cells were collected, washed with PBS and fixed for $10 \mathrm{~min}$ in PBS containing $4 \%$ paraformaldehyde. After centrifugation, cells were resuspended in $5 \mu \mathrm{l} \mathrm{of} 1 \mu \mathrm{g} \mathrm{ml}^{-1}$ DAPI. Nuclear morphology was monitored under a fluorescence microscope (Leica DM RB). 


\section{Analysis of DNA fragmentation}

DNA fragments were extracted and separated by electrophoresis in agarose gels according to Duke et $a^{58}$ with minor modifications. Briefly, $2 \times 10^{6}$ cells were incubated with cations for defined periods, washed twice in PBS and then lysed with $30 \mu \mathrm{l}$ of a buffer containing $10 \mathrm{mM}$ Tris (pH 7.5), $5 \mathrm{mM}$ EDTA, and $0.5 \%$ Triton X-100 for $30 \mathrm{~min}$ at room temperature. Cell lysates were centrifuged at $15000 \times g$ for $20 \mathrm{~min}$ and the supernatants incubated with proteinase $\mathrm{K}$ $\left(0.2 \mathrm{mg} \mathrm{ml}^{-1}\right)$ and ribonuclease $A\left(0.1 \mathrm{mg} \mathrm{ml}^{-1}\right)$ at $42^{\circ} \mathrm{C}$ for $1 \mathrm{~h}$. The samples were electrophoresed in a $2 \%$ agarose gel in $0.5 \times$ TBE running buffer ( $4.5 \mathrm{mM}$ Tris, $4.5 \mathrm{mM}$ boric acid, $62.5 \mu \mathrm{M}$ EDTA) containing ethidium bromide $\left(10 \mu \mathrm{g} \mathrm{ml}^{-1}\right)$.

\section{Western blotting analysis}

Cells were lysed by incubation for $1 \mathrm{~h}$ on ice in lysis buffer $(50 \mathrm{mM}$ Tris $\mathrm{pH} 8,150 \mathrm{mM} \mathrm{NaCl}, 1 \%$ Nonidet P-40, 2 mM Pefablock from Interchim (Montluçon, France), $1 \mu \mathrm{M} \mathrm{ml}^{-1}$ Aprotinine, $10 \mu \mathrm{g} \mathrm{ml}^{-1}$ leupeptine, $2 \mu \mathrm{g} \mathrm{ml}^{-1}$ Pepstatin A and $100 \mu \mathrm{g} \mathrm{ml}^{-1}$ Soybean Trypsine inhibitor all from Sigma (St. Louis, MO, USA). The lysate was centrifuged for $30 \mathrm{~min}$ at $13000 \times \mathrm{g}$ at $4^{\circ} \mathrm{C}$ and the protein concentration of the supernatant determined (micro-BCA protein assay, Pierce Chemical Co., Rockford, IL, USA). Cell lysate ( $40 \mu \mathrm{g}$ of the protein) was boiled for $5 \mathrm{~min}$ in $1 \times$ sample buffer and resolved by 7.5 or $15 \%$ SDSPAGE. Proteins were then electroblotted onto $0.45 \mu \mathrm{m}$ pore size nitrocellulose filters, and the filters were blocked for $1 \mathrm{~h}$ with $5 \%$ nonfat milk in PBS, $0.1 \%$ Tween-20. The filters were then incubated $1 \mathrm{~h}$ at room temperature with anti-ICE mAb (2 $\mu \mathrm{g} \mathrm{ml}^{-1}$, ICE p10 (C20) Santa Cruz Biotechnology, Santa Cruz, CA, USA) or CPP32 mAb $\left(1 \mu \mathrm{g} \mathrm{ml}^{-1}\right.$, polyclonal Rabbit Anti-Caspase-3 antiserum, Pharmingen, San Diego, CA, USA) or PARP mAb $\left(1 \mu \mathrm{g} \mathrm{ml}^{-1}, \mathrm{C} 2.10\right.$ was obtained from Dr G. Poirier, Quebec, Canada). The blots were washed three times for 10 min with $0.2 \%$ Tween 20 in PBS and incubated for $1 \mathrm{~h}$ with peroxidase-labeled anti-mouse or rabbit immunoglobulin (1/ 5000). Blots were then developed using an enhanced chemiluminescence detection system (ECL, Amsersham Corp., UK).

\section{Acknowledgements}

This work was supported by INSERM and grants from Association pour la Recherche sur le Cancer (ARC, Villejuif, France). N. Schrantz receives a fellowship from MESR (Ministère de l'Enseignement Supérieur et de la Recherche) and D.A. Blanchard from ARC. We wish to thank Dr Gilles Bénichou for a critical review of our manuscript and $\mathrm{Dr} \mathrm{J}$. Bertoglio for providing us with the $\mathrm{Bcl}-2$ plasmid.

\section{References}

1. Ellis RE, Yuan JY and Horvitz HR. (1991) Mechanisms and functions of cell death. Annu. Rev. Cell. Biol. 7: 663-698

2. Steller H (1995) Mechanisms and genes of cellular suicide. Science 267: 1445 1449

3. Martin SJ and Green DR (1995) Protease activation during apoptosis: death by a thousand cuts? Cell $82: 349-352$

4. Cohen JJ (1993) Apoptosis. Immunol. Today 14: 126-130

5. Wyllie AH, Kerr JF and Currie AR (1980) Cell death: the significance of apoptosis. Int. Rev. Cytol. 68: 251-306

6. Krammer PH, Behrmann I, Daniel P,Dhein J and Debatin KM (1994) Regulation of apoptosis in the immune system. Curr. Opin. Immunol. 6: 279-289

7. Kroemer G (1997) Mitochondrial implication in apoptosis. Towards an endosymbiont hypothesis of apoptosis evolution. Cell Death Differ. 4: 443-456
8. Collins RJ, Verschuer LA, Harmon BV, Prentice RL, Pope JH and Kerr JF (1989) Spontaneous programmed death (apoptosis) of B-chronic lymphocytic leukaemia cells following their culture in vitro. Br. J. Haematol. 71: 343-350

9. Chaouchi N, Vazquez A, Galanaud P and Leprince C (1995) B cell antigen receptor-mediated apoptosis. Importance of accessory molecules CD19 and CD22, and of surface IgM cross-linking. J. Immunol. 154: 3096-3104

10. Hasbold $J$ and Klaus GG (1990) Anti-immunoglobulin antibodies induce apoptosis in immature B cell lymphomas. Eur. J. Immunol. 20: 1685-1690

11. Ishigami T, Kim KM, Horiguchi Y, Higaki Y, Hata D, Heike T, Katamura K, Mayumi $M$ and Mikawa $H$ (1992) Anti-IgM antibody-induced cell death in a human B lymphoma cell line, B104, represents a novel programmed cell death. J. Immunol. 148: 360-368

12. Daniel PT and Krammer PH (1994) Activation induces sensitivity toward APO-1 (CD95)-mediated apoptosis in human B cells. J. Immunol. 152: 5624 - 5632

13. Vazquez A, Auffredou MT, Chaouchi N, Taieb J, Sharma S, Galanaud Pand Leca G(1991) Differential inhibition of interleukin 2-and interleukin 4-mediated human $B$ cell proliferation by ionomycin: a possible regulatory role for apoptosis. Eur. J. Immunol. 21:2311-2316

14. Fluckiger AC, Durand I and Banchereau J (1994) Interleukin 10 induces apoptotic cell death of B-chronic lymphocytic leukemia cells. J. Exp. Med. 179: 91-99

15. Mainou-Fowler T, Craig VA, Copplestone JA, Hamon MD and Prentice AG (1994) Interleukin-5 (IL-5) increases spontaneous apoptosis of B-cell chronic lymphocytic leukemia cells in vitro independently of bcl-2 expression and is inhibited by IL-4. Blood 84: 2297-2304

16. Mentz F, Mossalayi MD, Ouaaz F, Baudet S, Issaly F, Ktorza S, Semichon M, Binet JL and Merle-Beral H (1996) Theophylline synergizes with chlorambucil in inducing apoptosis of B-chronic lymphocytic leukemia cells. Blood 88: 21722182

17. Robertson LE, Chubb S, Meyn RE, Story M, Ford R, Hittelman WN and Plunkett W (1993) Induction of apoptotic cell death in chronic lymphocytic leukemia by 2chloro-2'-deoxyadenosine and 9-beta-D-arabinosyl-2-fluoroadenine. Blood 81: $143-150$

18. Buschle M, Campana D, Carding SR, Richard C, Hoffbrand AV and Brenner MK (1993) Interferon gamma inhibits apoptotic cell death in B cell chronic lymphocytic leukemia. J. Exp. Med. 177: 213-218

19. Chaouchi N, Wallon C, Goujard C, Tertian G, Rudent A, Caput D, Ferrera P, Minty A, Vazquez A and Delfraissy JF (1996) Interleukin-13 inhibits interleukin-2induced proliferation and protects chronic lymphocytic leukemia B cells from in vitro apoptosis. Blood 87: 1022-1029

20. Dancescu M, Rubio-Trujillo M, Biron G, Bron D, Delespesse G and Sarfati M (1992) Interleukin 4 protects chronic lymphocytic leukemic B cells from death by apoptosis and upregulates Bcl-2 expression. J. Exp. Med. 176: $1319-1326$

21. Francia di Celle $P$, Mariani $S$, Riera $L$, Stacchini $A$, Reato $G$ and Foa $R$ (1996) Interleukin-8 induces the accumulation of B-cell chronic lymphocytic leukemia cells by prolonging survival in an autocrine fashion. Blood 87 : 4382-4389

22. Huang RW, Tsuda Hand TakatsukiK (1993) Interleukin-2 prevents programmed cell death in chronic lymphocytic leukemia cells. Int. J. Hematol. 58: 83-92

23. Panayiotidis P, Ganeshaguru K, Jabbar SA and Hoffbrand AV (1994) Alphainterferon (alpha-IFN) protects B-chronic lymphocytic leukaemia cells from apoptotic cell death in vitro. Br. J. Haematol. 86: 169-173

24. Reittie JE, Yong KL, Panayiotidis $P$ and Hoffbrand AV (1996) Interleukin-6 inhibits apoptosis and tumour necrosis factor induced proliferation of B-chronic lymphocytic leukaemia. Leuk. Lymphoma 22: 83-90

25. Ning ZQ, Norton JD, Li J and Murphy JJ (1996) Distinct mechanisms for rescue from apoptosis in Ramos human B cells by signaling through CD40 and interleukin-4 receptor: role for inhibition of an early response gene, Berg36. Eur. J. Immunol. 26: 2356-2363

26. Osorio LM, De Santiago A, Aguilar-Santelises M, Mellstedt $H$ and Jondal M (1997) CD6 ligation modulates the $\mathrm{Bcl}-2 / \mathrm{Bax}$ ratio and protects chronic lymphocytic leukemia B cells from apoptosis induced by anti-IgM. Blood 89: 2833-2841

27. Liu YJ, Mason DY, Johnson GD, Abbot S, Gregory CD, Hardie DL, Gordon J and MacLennan IC (1991) Germinal center cells express bcl-2 protein after activation by signals which prevent their entry into apoptosis. Eur. J. Immunol. 21: 19051910 
28. Cohen GM (1997) Caspases: the executioners of apoptosis. Biochem. J. 326: $1-16$

29. Henkart PA (1996) ICE family proteases: mediators of all apoptotic cell death? Immunity 4: 195-201

30. Fraser A and Evan G (1996) A license to kill. Cell 85: 781-784

31. Martin SJ, Mazdai G, Strain JJ, CotterTG and Hannigan BM (1991) Programmed cell death (apoptosis) in lymphoid and myeloid cell lines during zinc deficiency. Clin. Exp. Immunol. 83: 338-343

32. Bicknell GR, Snowden RT and Cohen GM (1994) Formation of high molecular mass DNA fragments is a marker of apoptosis in human leukaemic cell line, U937. J. Cell. Sci. 107: 2483-2489

33. Cohen JJ and Duke RC (1984) Glucocorticoid activation of a calcium-dependent endonuclease in thymocyte nuclei leads to cell death. J. Immunol. 132: 38-42

34. Perry DK, Smyth MJ, Stennicke HR, Salvesen GS, Duriez P, Poirier GG and Hannun YA (1997) Zinc is a potent inhibitor of the apoptotic protease, caspase-3. A novel target for zinc in the inhibition of apoptosis. J. Biol. Chem. 272: 1853018533

35. Takahashi A, Alnemri ES, Lazebnik YA, Fernandes-Alnemri T, Litwack G, Moir RD, Goldman RD, Poirier GG, Kaufmann SH and Earnshaw WC (1996) Cleavage of lamin A by Mch2 alpha but not CPP32: multiple interleukin 1 beta-converting enzyme-related proteases with distinct substrate recognition properties are active in apoptosis. Proc. Natl. Acad. Sci. USA 93: 8395-8400

36. Archibald FS and Fridovich I (1982) The scavenging of superoxide radical by manganous complexes: in vitro. Arch. Biochem. Biophys. 214: 452-463

37. OishiKand Machida K (1997) Inhibition of neutrophil apoptosis by antioxidants in culture medium. Scand. J. Immunol. 45: 21-27

38. Desole MS, Sciola L, Delogu MR, Sircana S and Migheli R (1996) Manganese and 1-methyl-4-(2'ethylphenyl)-1,2,3,6-tetrahydropyridine induce apoptosis in PC12 cells. Neurosci. Lett. 209: 193-196

39. Martin SJ, Amarante-Mendes GP, Shi L, Chuang TH, Casiano CA, O'Brien GA, Fitzgerald P, Tan EM, Bokoch GM, Greenberg AH and Green DR (1996) The cytotoxic cell protease granzyme B initiates apoptosis in a cell-free system by proteolytic processing and activation of the ICE/CED-3 family protease, CPP32, via a novel two-step mechanism. Embo. J. 15: 2407-2416

40. Graham DG (1984) Catecholamine toxicity: a proposal for the molecular pathogenesis of manganese neurotoxicity and Parkinson's disease. Neurotoxicology 5: 83-95

41. Spina MB and Cohen G (1989) Dopamine turnover and glutathione oxidation: implications for Parkinson disease. Proc. Natl. Acad. Sci. USA 86: 1398-1400

42. Cossarizza A, Franceschi C, Monti D, Salvioli S, Bellesia E, Rivabene R, Biondo L, Rainaldi G, Tinari A and Malorni W (1995) Protective effect of N-acetylcysteine in tumor necrosis factor-alpha-induced apoptosis in U937 cells: the role of mitochondria [published erratum appears in Exp Cell Res 1996 Jan 10; 222(1):251-3]. Exp. Cell. Res. 220: 232-240

43. Kohanski RA (1989) Insulin receptoraggregation and autophosphorylation in the presence of cationic polyamino acids. J. Biol. Chem. 264: 20984-20991

44. Morrison BD, Feltz SM and Pessin JE (1989) Polylysine specifically activates the insulin-dependent insulin receptor protein kinase. J. Biol. Chem. 264: $9994-$ 10001
45. Koland JG and Cerione RA (1988) Growth factor control of epidermal growth factor receptor kinase activity via an intramolecular mechanism. J. Biol. Chem. 263: $2230-2237$

46. Mohammadi M, Honegger A, Sorokin A, Ullrich A, Schlessinger J and Hurwitz DR (1993) Aggregation-induced activation of the epidermal growth factor receptor protein tyrosine kinase. Biochemistry 32: $8742-8748$

47. Wente SR, Villalba M, Schramm VL and Rosen OM (1990) Mn2(+)-binding properties of a recombinant protein-tyrosine kinase derived from the human insulin receptor. Proc. Natl. Acad. Sci. USA 87: 2805-2809

48. Woo M, Hakem R, Soengas MS, Duncan GS, Shahinian A, Kagi D, Hakem A, McCurrach M, Khoo W, Kaufman SA, Senaldi G, Howard T, Lowe SW and Mak TW (1998) Essential contribution of caspase 3/CPP32 to apoptosis and its associated nuclear changes. Genes Dev. 12: 806-819

49. Matsushita K, Kitagawa K, Matsuyama T, Ohtsuki T, Taguchi A, Mandai K, Mabuchi T, Yagita Y, Yanagihara T and Matsumoto M (1996) Effect of systemic zinc administration on delayed neuronal death in the gerbil hippocampus. Brain Res. 743: 362-365

50. Treves S, Trentini PL, Ascanelli M, Bucci G and Di Virgilio F (1994) Apoptosis is dependent on intracellular zinc and independent of intracellular calcium in lymphocytes. Exp Cell Res 211: 339-343

51. Shiokawa D, Ohyama H, Yamada T, Takahashi K and Tanuma S (1994) Identification of an endonuclease responsible for apoptosis in rat thymocytes. Eur. J. Biochem. 226: 23-30

52. Shen ZX, Chen GQ, Ni JH, Li XS, Xiong SM, Qiu QY, Zhu J, Tang W, Sun GL, Yang KQ, Chen Y, Zhou L, Fang ZW, Wang YT, Ma J, Zhang P, Zhang TD, Chen SJ, Chen Z and Wang ZY (1997) Use of arsenic trioxide (As203) in the treatment of acute promyelocytic leukemia (APL): II. Clinical efficacy and pharmacokinetics in relapsed patients. Blood 89: 3354-3360

53. Soignet SL, Maslak P, Wang ZG, Jhanwar S, Calleja E, Dardashti LJ, Corso D, DeBlasio A, Gabrilove J, Scheinberg DA, Pandolfi PP and Warrell RP Jr (1998) Complete remission after treatment of aucte promyelocytic leukemia with arsenic trioxide [see comments]. N. Engl. J. Med. 339: 1341-1348

54. Zhang W, Ohnishi K, Shigeno K, Fujisawa S, Natio K, Nakamura S, Takeshita K, Takeshita A and Ohno R (1998) The induction of apoptosis and cell cycle arrest by arsenic trioxide in lymphoid neoplasms. Leukemia 12: 1383-1391

55. Leca G, Benichou G, Bensussan A, Mitenne F, Galanaud P and Vazquez A (1991) Respiratory burst in human B lymphocytes. Triggering of surface Ig receptors induces modulation of chemiluminescence signal. J. Immunol. 146: 3542-3549

56. Chaouchi N, Wallon C, Taieb J, Auffredou MT, Tertian G, Lemoine FM, Delfraissy JF and Vazquez A (1994) Interferon-alpha-mediated prevention of in vitro apoptosis of chronic lymphocytic leukemia B cells: role of bcl-2 and c-myc. Clin Immunol. Immunopathol. 73: 197-204

57. Nicoletti I, Migliorati G, Pagliacci MC, Grignani F and Riccardi C (1991) A rapid and simple method for measuring thymocyte apoptosis by propidium iodide staining and flow cytometry. J. Immunol. Methods 139: 271-279

58. Duke RC, Chervenak R and Cohen JJ (1983) Endogenous endonucleaseinduced DNA fragmentation: an early event in cell-mediated cytolysis. Proc. Natl Acad. Sci. USA 80: 6361-6365 